\title{
Meta-analysis on the study with concept maps on the medical field
}

\author{
NiCOARA SERGIU MIHAI ${ }^{1}$ \\ SZABO BIANCA AURORA ${ }^{2}$ \\ MiCU CARMEN MARIA ${ }^{2}$ \\ BADEA ALEXANDRU FLORIN ${ }^{2}$
}

\begin{abstract}
The present study wants to see if and to what extent, the type of teaching and learning according to the concept maps method has an effect in the medical field and predominantly in teaching anatomy. In this respect, a total of 13 relevant articles have been searched for and found. As a measuring tool the results obtained by the authors were used as grades or scores obtained by testing on experimental vs. control groups. The overall effect was measured for the preclinical and clinical domains, after which relevant factors were sought that could mediate, in one way or another, the overall effect. From our data we found enhanced effects evident both in general and in both of the mentioned fields, so as to, of the mediating factors, to be noticed among others, particularly the actual teaching of concept maps, which by its duration could ease or, conversely, hinder the learning process.
\end{abstract}

\section{Keywords}

concept map, teaching anatomy, learning anatomy with concept maps, effects of studying with concept maps, concept maps in medical field.

1. Iuliu Hatieganu University of Medicine, Faculty of General Medicine, Department of Human Anatomy and Embriology, Cluj-Napoca, Romania.

Address for correspondence: University of Medicine, Anatomy department, Victor Babes street, no. 8, Cluj-Napoca, Romania. Tel: 0040-264-597256. E-mail address:

nicoarasergiu@yahoo.com

2. Iuliu Hatieganu University of Medicine, Faculty of General Medicine, Department of Human Anatomy and Embriology, Cluj-Napoca, Romania 


\section{References}

Alvermann, D. (1981). The compensatory effect of graphic organizers on descriptive texts. Journal of Educational Research, 75, 44-48.

Amer, A. A. (1994). The effect of knowledge-map and underlining training on the reading comprehension of scientific texts. English for Specific Purposes, 13, 3445.

Ausubel, D. P. (1968). Educational psychology: A cognitive view. New-York: Holt Rinehart \& Winston.

Baddeley, A. (1992). Is working memory working? The Fifteenth Bartlett lecture. Quarterly Journal of Experimental Psychology, 44A, 1-31.

Baig M., Tariq S., Rehman R., Ali S. \& Gazzaz Z. J. (2016). Concept mapping improves academic performance in problem solving questions in Biochemistry subject. Pak. Journal Medical Science, 32 (4).

Balaid A., Abd Rozan M. Z., Hikmi S. N. \& Memon J. (2016). Knowledge maps: A systematic literature review and directions for future research. International Journal of Information Management. 36, 451-475.

Bergman E. M., de Bruin A. B. H., Herrler A., Verheijen I. W. H., Scherpbier A. J. J. A. \& van der Vleuten C. P. M. (2013). Students' perceptions of anatomy across the undergraduate problem-based learning medical curriculum: a phenomenographical study. BMC Medical Education 13, 152.

Borenstein, M., Hedges, L., Higgins, J., \& Rothstein, H. Englewood. (2005). Comprehensive meta-analysis, version 2.: NJ: Biostat.

Burdo J. \& O'Dwyer L. (2015). The effectiveness of concept mapping retrieval practice as learning strategies in an undergraduate physiology course. Advances in Physiology Education, 39, 335-340.

Carr-Lopez S.M., Galal S. M., Vyas D., Patel R. A. \& Gnesa E.H. (2014). The utility of concept maps to facilitate higher-level learning into a large classroom setting. American Journal of Pharmaceutical Education, 78(9), 170.

Cheema A. B. \& Mirza M. S. (2013). Effect of concept mapping on students' academic achievements. Journal of Research and Reflections in Education, 7(2), 125-132. 
Chei-Chiang Chiou (2008). The effect of concept mapping on students' learning achievements and interests. Inovation in Education and Teaching International, 375-387.

Chmielewski, T. L., \& Dansereau, D. F. (1998). Enhancing the recall of text: Knowledge mapping training promotes implicit transfer. Journal of Educational Psychology, 90, 407-413.

Cohen, J. (1977). Statistical power analysis for the behavioral sciences (revised edition ed.).New York: Academic Press.

D’Antony A., Zipp G. P., Olson V. G. \& Cahill T. F. (2010). Does the mind map learning strategy facilitate information retrieval and critical thinking in medical students? BMC Medical Education, 10- 61.

Donnelly J. P. (2016). A systematic review of concept mapping dissertations. Evaluation and Program Planning, 186-193.

Foos, P. W. (1995). The effect of variations in text summarization opportunities on test performance. Journal of Experimental Education, 63, 89-95.

Gonzalez H. L., Palencia A. P., Umana L. A., Galindo L., \& Villafrade L. A. (2008). Mediated learning experience and concept maps: a pedagogical tool for achieving meaningful learning in medical physiology students. Advances in Physiology Education, 312-316.

Griffin, M. M., \& Robinson, D. H. (2000). Role of mimeticism and spatiality in textual recall. Contemporary Educational Psychology, 25, 125-149.

Griffin, M. M., \& Robinson, D. H. (2005). Does spatial or visual information in maps facilitate text recall? Reconsidering of conjoint retention hypothesis. Educational Technology Research and Development, 53, 23-36.

Hedges, L. V. \& Olkin, I. (1985). Statistical methods for meta-analysis. San Diego, CA: Academic Press.

Holley, C., \& Dansereau, D. (1984). Spatial learning strategies. New York: Academic Press.

Holliday, W. G., Brunner L.L., \& Donais, E.L. (1977). Differential cognitive and affective responses to flow diagrams in science. Journal of Research in Science Teaching, 14, 129-138.

Hunter J., \& Schimdt F. (2004). Methods of Meta-Analysis: Correcting Error and Bias in Research Findings, Sage Publications, 2 edition. 
Ives B., \& Hoy, C. (2003). Graphic organizers applied to higher-level secondary mathematics, Learning Disabilities Research \& Practice, 18, 36-51.

Jegede O. J., Alaiyemola F. F. \& Okebukola P. A. (1990). The effect of concept mapping on students' anxiety and achievement in biology. Journal in research in science teaching, 27, 951-960.

Kane M. \& Trochim W.M.K. (2016). Concept mapping for planning and evaluation. Thousand Oaks, CA: SAGE Publications.

Kinchin I. M. (2016). Visualising powerful knowledge to develop the expert student. Rotterdam: Sense Publishers.

Lambiotte, J. G., \& Dansereau, D. F. (1992). Effects of knowledge maps and prior knowledge on recall of science lecture content. Journal of Experimental Education, 68, 119-133.

Larkin, J. H., \& Simon, H. A. (1987). Why a diagram is (sometimes) worth ten thousand words. Cognitive Science, 11, 65-99.

Lipsey, M. W. \& Wilson, D. B. (2001). Practical meta-analysis. Applied Social Research Methods Series (Vol. 49). Thousand Oaks, CA: SAGE Publications.

Luchembe D., Chinyama K., Jumbe J. (2014). The effect of using concept mapping on students' attitude and achievement when learning the physics topic of circular and rotational motion. European Journal of Physics Education, 5, 10-29.

Lym K. Y., Lee H. W., \& Grabowsky B. (2008). Does concept-mapping strategy work for everyone? The levels of generativity and learners' self-regulated learning skills. British Journal of Educational Technology, 40(4), 606-618.

Mayer, R. E. (1979). Can advance organizers influence meaningful learning? Review of Educational Research, 49, 371-383.

Mayer, R. E. (2001). Multimedia learning. Cambridge, UK: Cambridge University Press.

McCagg, E. C., \& Dansereau, D. F.(1991). A convergent paradigm for examining knowledge mapping as a learning strategy. Journal of Educational Research, $84,317-324$.

McGaghie W.C., McCrimmon D. R., Mitchell D., Thompson A., \& Ravitch M. (2000). Quantitative concept mapping in pulmonary physiology: comparison between student and faculty knowledge structures. Advances in Physiology Education, 72-81. 
Moyer, J. C., Sowder, L., Threadgill-Sowder, J., \& Moyer, M. B., (1984). Story problem formats: Drawn versus verbal versus telegrafic. Journal for Research in Mathematics Education, 15, 342-351.

Novak, J. D., \& Gowin, D. B. (1984). Learning how to learn. New York: Cambridge University Press.

Nesbit, J. C., \& Adesope, O. (2006). Learning with Concept and Knowledge Maps: A Meta-Analysis. Review of Educational Research, 76 (3), 413-448.

O’Donnell, A. M., Dansereau, D. F., \& Hall, R. H. (2002). Knowledge maps as scaffolds for cognitive processing. Educational Psychology Review, 14, 71-86.

Ogonnaya U. P., Okafor G., Abonyi O. S. \& Ogama J. O. (2016). Effects of concept mapping instruction approach on students' achievement in basic science. Journal of Education and Practice,7 (8), 79-84.

Orwin R. G. (1983). A Fail-Safe N for Effect Size in Meta-Analysis. Journal of Educational Statistics, 8, (2), 157-159.

Otor E. E. (2013). Effects of concept mapping strategy on students' achievement in difficult chemistry concepts. Educational Research, 4 (2), 182-189.

Paivio, A. (1986). Mental representations: A dual coding approach. Oxford, UK: Oxford University Press.

Patterson, M. E., Dansereau, D. F., \& Newbern, D. (1992). Effects of communication aids and strategies on cooperative teaching. Journal of Educational Psyvhology, 84, 453-461.

Patterson, M. E., Dansereau, D. F., \& Wiegman, D. A. (1993). Receiving information during a cooperative episode: Effects of communication aids and verbal ability. Learning and Individual Differences, 5, 1-11.

Rewey, K. L., Dansereau, D., Dees, S., Skaggs, L., \& Pitre, U., (1992). Scripted cooperation and knowledge map supplements: Effects on the recall of biological and statistical information. Journal of Experimental Education, 60, 93-107.

Richardson M., Abraham C., \& Bond R. (2012) Psychological correlates of University students' academic performance: A Systematic Review and Meta-analysis. American Psychological Association; Psychological Bulletin.138, 353-387.

Rosenthal, R. (1991). Meta-analytic procedures for social research (rev. ed).. Thousand Oaks,CA: Sage Publications. 
Roth, W. M., Roychoudhury, A. (1993). The concept map as a tool for the collaborative construction of knowledge: A microanalysis of highschool physics students. Journal of Research in Science Teaching, 30, 503-534.

Roth, W. M., Roychoudhury, A. (1994). Science discourse through collaborative concept-mapping: New perspectives for the teacher. International Journal of Science Education, 6, 437-455.

Saeidifard F., Heidari K., Foroughi M. \& Soltani A. (2014). Concept mapping as a method to teach an evidence-based educated medical topic: a comparative study in medical students. Journal of Diabetes and Metabolic Disorders, 13, 86.

Stensvold, M. S., Wilson, J. T. (1990). The interaction of verbal ability with concept mapping in learning from a chemistry laboratory activity. Science Education, 74, 473-480.

Stock, W. A., Kulhavy, R. W., Peterson, S. E., Hancock, T. E., \& Verdi M. P. (1995). Mental representations of maps and verbal descriptions: Evidence they may affect text memory differently. Contemporary Educational Psychology, 20, 237 256.

Stoyanova, N., \& Kommers, P.(2002). Concept mapping as a medium of shared cognitionin computer-supported collaborative problem solving. Journal of Interactive Learning Research, 13, 111-133.

Surapaneni K. M., \& Tekian A. (2013). Concept mapping enhances learning of biochemistry. Medical Education, 18.

van Boxtel, C., van der Linden, J., Roelofs, E., \& Erkens G. (2002). Collaborative concept mapping: Provoking and supporting meaningful discourse. Theory Into Practice, 41, 40-46.

Verdi, M. P., \& Kulhavy, R. W. (2002). Learning with maps and texts: An overview. Educational Psychology Review, 14, 27-46.

Vink S. C., Tartvijk J. V., Bolk J. \& Verloop N. (2015). Integration of basic and basic scienes in concept maps: a mixed-method study on teacher learning. BMC Medical Education, 15-20.

Wallace, D. S., West, S. C., Ware, A. M., \& Dansereau, D. F. (1998). The effect of knowledge maps that incorporate gestalt principles on learning. Journal of Experimental Education, 67, 5-16. 
Weinstein, C. E., \& Mayer, R. E. (1986). The teaching of learning strategies. In M. C. Wittrock (Ed.), Handbook on Research in Teaching (3rd ed., pp. 315-327). New York: Macmillan.

Wiegmann, D. A., Dansereau, D. F., \& McCagg, E. C. (1992). Effects of knowledge map characteristics on information processing. Contemporary Educational Psychology, 17, 136-155.

Wilson A. \& Kim W. (2016). The effects of concept mapping and academic selfefficacy on mastery goals and reading comprehension achievement. Canadian Center of Science and Education, 9 (3), 12-23.

Winn, W. (1991). Learning from maps and diagrams. Educational Psychology Review, 3, 211-247.

Zadeh N. R., Gandomani H. S., Delaram M., \& Yekta Z. P. (2015). Comparing the effect of concept mapping and conventional methods on nursing students' practical skill score. Nurse Midwefery stud., 4(3). 